УДК [262.145УГКЦ:355.34 (100)]"1914/1918"

https://doi.org/10.33402/zuz-2020-158-184

Nataliia KOLB

PhD, Senior Researcher

Ivan Krypiakevych Institute of Ukrainian Studies

National Academy of Sciences of Ukraine

Senior Researcher

Institute of Religious Studies

branch of the Lviv Museum of the History of Religion

ORCID: https://orcid.org/0000-0003-4449-1991

e-mail:nata_kolb@ukr.net

Iryna ORLEVYCH

PhD, Head of the Department of Modern History of Ukraine Ivan Krypiakevych Institute of Ukrainian Studies

National Academy of Sciences of Ukraine

Senior Researcher

Institute of Religious Studies

branch of the Lviv Museum of the History of Religion

ORCID:https://orcid.org/0000-0002-7530-9833

e-mail:i.orlevych@gmail.com

\title{
A PROSOPOGRAPHIC PORTRAIT OF THE UKRAINIAN GREEK CATHOLIC CHAPLAINS DURING THE FIRST WORLD WAR
}

The history of the formation and functioning of the institute of chaplaincy in the Greek Catholic Church (GCC) during the entry of Galicia into the Austro-Hungarian Empire has been outlined. In particular, the system of subordination of chaplains, their number, responsibilities, position in the hierarchical structure of the GCC have been indicated. The tasks and realities of the ministry of military clergymen with the outbreak of the First World War have been shown as well. It has been emphasized that the duties of chaplains included: conducting services in places of permanent and temporary deployment of units, confession of soldiers before battles, cultural and educational work with them, care for the sick and wounded in front infirmaries and hospitals, organization of burials and funeral services, keeping records in metric books and registration of military burials. Particular examples testify to the courage and sacrifice of Ukrainian chaplains. We have highlighted the importance of their service to support the morale, combat, national and patriotic spirit of soldiers, to meet the urgent need of soldiers for prayer and consolation, to establish communication with the command in the circumstances of being in a 
foreign language environment. Some chaplains, while being prisoners in war camps, performed pastoral services for their compatriots.

More than half of the chaplains of the First World War supported the national liberation struggle of Ukrainians, survived to the Soviet period, thus being under the rule of three foreign states: Austria-Hungary, the Republic of Poland and the Soviet Union. In all these periods, fidelity to their Church and people remained a characteristic feature of most of them.

The article is supplemented with appendices that contain the texts of sermons of chaplains, excerpts from reports, information from clerical press of that time.

Keywords: Galicia, Greek Catholic Church, First World War, Ukrainian chaplains, pastoral ministry, cultural and educational activities, prosopographic portrait.

The history of the Greek Catholic clergy throughout the XIX century was closely connected with the social and political life of Galician Ukrainians. Almost until the middle of the XIX century it was practically the only representative and defender of the interests of its own people, taking over the functions of the political and intellectual elite. Gradually, in the process of forming an increasing number of Ukrainian secular intelligentsia, these responsibilities passed to secular circles. However, the Greek Catholic Church continued to be an active participant in the socio-political life of the region ${ }^{1}$. The clergy used a wide range of means - from spiritual and religious to socio-political - to establish communication with the parishioners, cultivate religious and civic consciousness; demonstrated an active social position, the ability to mobilize and self-organize to defend the needs, rights and dignity of the Church and its people ${ }^{2}$.

With the outbreak of World War I, Galicia as part of the Austro-Hungarian Empire almost immediately found itself at the forefront of hostilities. The Austrian authorities began the forced mobilization of the male population. Along with numerous Ukrainian servicemen, Greek Catholic chaplains were called up for service ${ }^{3}$.

In this study, we aim to analyze the state of the institute of chaplaincy in the Greek Catholic Church (the GCC) in Galicia in the second half of XIX - early XX century; to cover the main activities of Ukrainian Greek Catholic clergy during the First World War; to compile a prosopographic portrait of the pastors who formed this category of clergy.

A valuable source for covering of this topic is the collection «Military Clergymen of the Ukrainian Galician Army», compiled and published by the former chaplain priest Ivan Lebedovych ${ }^{4}$. And although the main attention in it is focused on the events of the

1 Колб Н. «3 Богом за Церкву і вітчизну»: греко-католицьке парафіяльне духовенство в Галичині у 90-х роках ХІХ століття. Жовква, 2015. С. 137-141.

2 Колб Н. «...Вітцеві нічого не є чуже, що синів, дітей єго обходить»: внесок греко-католицького духовенства у формування засад громадянського суспільства в Галичині (кінець ХІХ століття). Взаємодія інституиій держави і громадянського суспільства в Украйні: західні землі (кінець XIX - початок XXI cm.). Львів, 2017. С. 493-512; Кісь Н. Пам’ять та ідентичність українських греко-католиків. Про джерела історичної політики УГКЦ. Львів, 2018. $184 \mathrm{c}$.

3 Забанджала М. Лицарі духа. Військове капеланство УГКЦ ХІХ-ХХ століть у біографіях. Львів, 2018. С. 42.

4 Лебедович I. Полеві духовники Української Галицької Армії. У 45-річчя участи у визвольних змаганнях. (Матеріяли до історії). Вінніпег, 1963. 
Ukrainian liberation struggle of 1918-1921, the work also contains a lot of information about the ministry of the clergy of the GCC during World War I. Religious practices in the ranks of the Legion of Ukrainian Sich Riflemen (Ukrainski Sichovi Striltsi - USS) and its pastors are mentioned in the book «For the Freedom of Ukraine. USS Historical Collection» ${ }^{5}$ and in the memoirs of the rifleman Mykhailo Ostroverkha ${ }^{6}$. The list of actual and reserve Greek Catholic chaplains (their surnames and names, place of priestly ministry, year of birth, ordination, marital status) is given in the schematisms of the Lviv Archdiocese for 1914 and 1918. We also used publications of church periodicals «Nyva» and «Bulletin of the Diocese of Przemyślı in our work, materials of the manuscript fund of the Lviv National Scientific Library named after V. Stefanyk, as well as historiographical works on this topic by other modern researchers - R. Velykyi ${ }^{7}$, M. Zabandzhala ${ }^{8}$, D. Zabzalyuk ${ }^{9}$, A. Lozynskyi ${ }^{10}$, S. Predka ${ }^{11}$.

The study of historical experience of the Ukrainian chaplaincy, the restoration of its best traditions and taking into account mistakes to avoid similar ones has become especially important in the realities of the hybrid war, which in 2014 was launched against Ukraine by the Russian Federation. This prompted the Ukrainian authorities to revive the institution of national chaplaincy ${ }^{12}$. In the modern war, military clergymen along with the soldiers defend

5 За волю України. Історичний збірник УСС. 1914-1964. Нью-Йорк, 1967.

6 Островерха М. Грозна калини в Українських Січових Стрільців. Нью-Йорк, 1962.

7 Великий Р. Благодійна та духовна опіка військовослужбовців в роки Першої світової війни. Християнська сакральна традииія: віра, духовність, мистеитво: матеріали IX Міжнародної конференції (м. Львів, 24 листопада 2016 р.). Львів, 2016.

8 Забанджала М. Лицарі духа...

9 Забзалюк Д. Душпастирська служба українських військових формацій першої половини ХХ ст. Львів, 2012. 188 с.

10 Лозинський А. Військове духовенство в роки Першої світової війни. Українознавство. 2017. № 1-2 (62-63).

11 Предка С. Капелани українських збройних формувань в Галичині 1914-1919 pр. (за матеріалами спогадів польових духівників). Історія релігій в Украӥні: наук. щорічник. Львів: Логос, 2016. Ч. 1. С. 472-482.

12 According to the Regulation «On the Service of the Military Clergy (Chaplaincy) in the Armed Forces of Ukraine» (Order of the Ministry of Defense of January 27, 2015), the main function of a military priest (chaplain) is the religious guardianship of the Armed Forces of Ukraine and their families. in order to encourage, deepen religious life, promote the strengthening of positive character traits and moral values. The main tasks of such priest include: «organizing and conducting prayers, services, blessings, solemn and memorial events and other religious rites and cults related to meeting the religious needs of servicemen, as well as significant state and religious dates; acquaintance of servicemen with the basic notions of religion; education of high patriotic feeling and fighting spirit in servicemen on the basis of moral and spiritual potential of religious and cultural heritage of the Ukrainian people; upbringing tolerant attitude to people with different worldviews and religious beliefs; acquaintance of the personnel with the history of national, cultural and religious formation of the Ukrainian statehood; assistance to servicemen in the development of their personal and collective moral qualities: brotherhood, courage, bravery, responsibility, moderation, sacrifice, discipline, prudence, etc.; establishing partnerships with representatives of religious organizations of various denominations operating in the locations of military units; providing servicemen with religious paraphernalia, clerical literature and other 
the independence of their homeland, serve as moral support for them, cultivate patriotic feelings in servicemen based on the religious and cultural heritage of the Ukrainian people.

In the vortex of the Great War. The beginning of the First World War arose the need to take care of the establishment of pastoral ministry of the Greek Catholic Church in new circumstances ${ }^{13}$. Among other things, the duty of the Church was the organization of spiritual services for Ukrainians, who en masse joined the ranks of numerous formations of the Austro-Hungarian army.

At that time, the Ukrainian chaplaincy already had a certain historical tradition. When, in the days of the Springtime of Nations (1848), with the permission of Emperor Ferdinand, Ukrainian political leaders began to form units of the National Guard, military clergy were appointed to provide spiritual care for them ${ }^{14}$. The next stage in the development of the institution of Greek Catholic chaplaincy in the region was the introduction of compulsory military service in Austria-Hungary in 1868. Therefore, the union hierarchy took appropriate measures to ensure that the pastoral activity of priests among the Ukrainian military took place on the official basis. Thus, the Galician metropolitan succeeded to gain from the authorities 17 full-time positions of Greek Catholic military clergy in the army: chaplains (feldcurates) - in regiments, deans (feldsuperiors) - in divisions ${ }^{15}$. The former were equated in rights and status to captains, and the latter to majors. Such priests wore military uniforms with a cross on their chests without the rank of officer. In the army, they were subordinate to the Roman Catholic military bishop of the Austrian army, and in ceremonial matters remained under the jurisdiction of their Greek Catholic bishops ${ }^{16}$.

things necessary to meet their religious needs; participation in the rehabilitation of servicemen who need psychological assistance; pastoral care for family members of servicemen; providing all possible pastoral care to all servicemen and members of their families; formation of fraternal relations among servicemen on the basis of the principles of solidarity, humanity and a sense of the sacredness of military service, etc.». URL: http://zakon3.rada.gov.ua/laws/show/ z016115https://zakon.rada.gov.ua/laws/show/z0161-15\#Text

13 On the ministry of the Greek Catholic parish clergy during the First World War, see, in particular: Kolb N. The Great War in the Light of Documents and Correspondence of the Galician Greek Catholic Parish Priest Isydor Hlynskyi. Intellectuals and the First World War. Kraków, 2018. P. 185-200.

14 Забзалюк Д. Душпастирська служба... С. 33.

15 Там само. С. 36.

16 Там само. С. 36-37; Шах С. Вступне слово. Полеві духовники Української Галицької Армії.. C. 16. 
In 1914 there were nine active Greek Catholic military chaplains: Kasiyan Kunitskyi ${ }^{17}$, Yosyf Kyshakevych ${ }^{18}$ (who were in Lviv), Anthonyi Kalyata ${ }^{19}$, Dr. Mykola Nahoryanskyi ${ }^{20}$ (in Vienna), Anthonyi Lomnytskyi ${ }^{21}$ (in Yaroslav), Volodymyr Sadovskyi22 (in Przemyśl), Feliks Shchurko ${ }^{23}$ (in Stanisław), Ivan Ozimkewych ${ }^{24}$ (in Tuzla, designated for spiritual care in Bosnia and Herzegovina) and Oleksandr Kowalskyi ${ }^{25}$ (in Innsbruck, designated for

17 Kasiyan Kunitskyi (1848-1918). He studied at the University of Vienna (1873-1979), was a cofounder of the Ternopil secret society of student youth «Community». Celibate. During the First World War he was chaplain of the 45th Infantry Division in Przemyśl (Забанджала М. Лицарі духа... С. 76).

18 Yosyf Kyshakevych (1872-1953). Until 1901 he was a priest in Przemyśl, and from 1902 to 1914 he was a military chaplain. One of the founders of the Boyan Choral Society. Author of about 200 works of sacred music (including «Soar among us, Christ, soar», 1908) and more than 100 works of secular one. He was buried in Lychakiv Cemetery in Lviv (Забанджала М. Лицарі духа... С. 69-71).

19 Anthonyi Kalyata (1882-?). Ordained in 1907. Celibate. Adviser to the Episcopal Consistory in Lviv. Military priest of II class, stationed in Vienna. The first clergyman at the Initial Command of the Ukrainian Galician Army in Khodoriv. Chaplain of the battle group «Lyutvyska» (Забанджала М. Лицарі духа... С. 67).

20 Mykola Nahoryanskyi (1879-1943). He studied in Innsbruck and Vienna. He got his doctorate degree in theology in 1908. Celibate. From 1910 he was a military chaplain in Lviv, later in Stanisław (1911-1912) and Vienna (1913-1914). Adviser to the Metropolitan Consistory with Kryloshan honours (1928-1938). Procurator at the Apostolic Nunciature (1927-1943) (Забанджала М. Лицарі духа... С. 79-80).

21 Anthonyi Lomnytskyi (1862-1933). Married (since 1891 - a widower). A teacher and prefect of the Przemyśl Theological Seminary (1894-1897), chaplain of the Austrian army in the 24th Infantry Division, he was taken prisoner by the Russians.

22 Volodymyr Sadovskyi (1869-1940). During 1894-1901 he was an employee and then administrator of the Ukrainian parish in Vienna. From 1901 he was a military chaplain in Przemyśl. In 1915, as a military priest of the 13th Zolochiv Regiment and the cavalry division of the Austrian army, he remained in Przemyśl, surrounded by the Russians, and was captured and taken to Siberia. He returned to Lviv in 1921. He served as the pastor of the Transfiguration Church. He donated his own library of 1,400 books, 12 manuscripts and about a hundred works of art to the National Museum in Lviv (Забанджала М. Лицарі духа... C. 91-92).

${ }^{23}$ Feliks Shchurko (1884-1914). Celibate. From 1910 - priest in the parish of Prnjavor (Bosnia and Herzegovina), where he founded a branch of the Ukrainian society «Prosvita». Stationed in Bosnia as a chaplain in the 8th Cavalry Division, died of cholera in Nagy Migali (Hungary) (Забаджала М. Лицарі духа... С. 109).

24 Ivan Ozimkevych - a presbyter of Eparchy in Stanisław, an honorary adviser to the episcopal consistory with Kryloshan honours and the right to wear a red belt and cap. Celibate. (Шематизмъ всего клира греко-католицкои Митрополичои Архіепархіи Львоิвскои на роิкъ 1914. Львоิвъ, 1913. С. 416).

25 Oleksandr Kowalskyi (1885 - after 1945). During 1910-1918 he was a military chaplain in Lviv (1910-1912), Innsbruck (1912-1914) and in Transcarpathia. Then in the 8th Cavalry Division (1914-1917), Kovel (1918) and again Lviv (1918-1924). Chaplain for political prisoners arrested by Poles and as well in Lviv hospitals for wounded UGA soldiers. Cathedral Kryloshan member of the Metropolitan Chapter (1922), Chancellor of the Chapter (1938-1945). In 1924 he was a pastor at the Psychiatric Institute in Lviv. In 1945 he was arrested by the Soviet authorities 
Tyrol). These positions were usually held by celibates, less often by widowers. These were mostly experienced and honored priests. It is no coincidence that most of the mentioned priests (five of them) had Kryloshan honours, and priest K. Kunitskyi, in addition to being an actual adviser to the Lviv metropolitan and episcopal consistories, also had the title of chamberlain of Pope Pius X and was awarded the Golden Cross of Merit with a crown ${ }^{26}$. Many priests traditionally applied for the position of chaplain of the Austrian army in peacetime, and those who received it were considered lucky. After all, this position implied rather light duties: to hold services on Sundays, holidays, as well as on the occasion of dynastic anniversaries, to take an oath from recruits, and to confess soldiers on Easter days. A significant advantage was a fairly high salary ${ }^{27}$.

In addition to the already mentioned current chaplains, 140 Greek Catholic priests joined the reserve of the GCC military clergy ${ }^{28}$. About half of them were enrolled to the army at the beginning of the First World War. According to the analysis of eparchial schematisms, this category was formed mostly by priests from among the lower parish clergy, sometimes by catechists of primary and secondary schools. Being part of the infantry and cavalry divisions of the Austro-Hungarian army, Ukrainian military priests served on the Russian, Italian, Serbian, and Albanian fronts ${ }^{29}$. The chaplains were also appointed to the Ukrainian Volunteer Legion of the USS ${ }^{30}$, specially created within the Austro-Hungarian army, and its reserve unit, the USS Company ${ }^{31}$.

Military clergymen conducted services in places of permanent and temporary deployment of units, conducted cultural and educational work (including in front reading rooms), confessed soldiers before battles, cared for the sick and wounded in front infirmaries and hospitals, organized burials and conducted memorial services ${ }^{32}$. They also corresponded

and sentenced to 5 years in a camp in the Tomsk region (Russia). He probably died in Siberia (Забанджала М. Лицарі духа... С. 70).

26 Шематизмъ всего клира греко-католицкои Митрополичои Архіепархіи Львоิвскои на роิкъ 1914. Львоิвъ, 1913. С. 416-417.

27 Лаба В., о., др. Українські полеві духовники наших пам’ятних днів. Полеві духовники Української Галицької Армії... С. 71.

28 Забзалюк Д. Душпастирська служба... С. 36-37; Шах С. Вступне слово... С. 16.

29 For more information, see: Забзалюк Д. Душпастирська служба... С. 36-37.

30 During 1914-1918, the military clergy in the ranks of the Ukrainian Sich Riflemen were priests Andriy Pshepyurskyi, Mykola Yizhak, Anatol Bazylevych and Yulian Fatsievych (Список українських католицьких капелянів в австрійській армії в Першій світовій війні. Полеві духовники Української Галицької Армії... С. 302).

31 Духовники УГА. Полеві духовники Украӥнської Галицької Армії... С. 193. The Ukrainian Volunteer Legion was a Ukrainian national military formation within the Austro-Hungarian Army, organized from volunteers on August 6, 1914. The Kish of the Ukrainian Sich Riflemen was a Ukrainian reserve unit created in early 1915 to replenish the Legion. The Kish was primarily tasked with recruiting volunteers and caring for wounded, sick, and injured riflemen and officers (See: Лазарович М. Легіон Українських січових стрільців: формування, ідея, боротьба. Тернопіль, 2016).

32 Духовники УГА. Полеві духовники Украӥнської Галицької Армії... C. 161. See also: Великий Р. Благодійна та духовна опіка військовослужбовців в роки Першої світової війни. С. 69-72; Лозинський А. Військове духовенство в роки Першої світової війни. С. 89-97. 
with the families of the dead, passed on to the relatives things of the deceased, kept the relevant metric books and registered military burials. Often as the oldest in rank, status, educational level in a certain structural unit of the Austrian army, a representative of Ukrainian nationality, the curate acted as a mediator between the Ukrainian soldiers and the command, conveying to the officer their requests (e.g. asking for a leave, etc.) ${ }^{33}$.

An important area of activity of military clergy, especially during the stay of military formations in the second echelon of defense, was cultural and educational work. There is evidence that a lot of effort in this area was made by the chaplain of the military units of the USS priest Mykola Yizhak ${ }^{34}$. The pastor joined the ideological, educational and culturaleducational work among the riflemen, deepened their national consciousness, consecrated the graves and monuments of riflemen ${ }^{35}$, and promoted the Galician USS as an influential factor in the liberation struggle of the Ukrainian people ${ }^{36}$.

One of the sources that gives us an idea of the ministry of Ukrainian Galician chaplains is the memories of the participants of those events. Naturally, the soldiers remembered the details of the great church holidays, which were accompanied by emphasized solemnity, were filled with the spirit of unique exaltation and joy, and at the same time - with regret that those holidays were not spent with the family. In particular, the rifleman M. Ostroverkha described the celebration of Christmas ${ }^{37}$ and Epiphany by soldiers with great warmth. «And Epiphany [...] was celebrated in traditional Ukrainian manner, - he recalled. - In the morning, as the sun was shining and to the sounds of our orchestra, in the presence of both units, our curate, at that time priest A. Pshepyurskyi, consecrated the water on Tudynka, near the village of Khatok. There was a monumental cross made of ice decorated with artificial flowers. This was the first, big, group holiday since the beginning of the war ${ }^{38}$. And during the Holy Week the chaplain organized for the riflemen the opportunity of Easter confession

33 Лаба В., о., др. Українські полеві духовники... С. 72.

34 Mykola Yizhak (1886-1919). In 1911 he was ordained by the Metropolitan of GCC Andrei Sheptytskyi in Lviv. From May 1916 he was chaplain of the Ukrainian Sich Riflemen Legion, worked in the Ternopil region (the village of Sosniv, now Terebovlya district, etc.). In 1919, by order of the Minister of War of the Western Ukrainian People's Republic, Colonel D. Vitovskyi, he became the Reverend of the State Secretariat for Military Affairs. During the UGA's retreat beyond Zbruch, he moved with it to Eastern Ukraine, where he died of typhus in December 1919.

35 After the First World War, the Day of the Holy Trinity became occasion to remember the fallen for Galician Ukrainians. Processions to the cemetery took place in the cities. Cathedral akathists were conducted in the villages. However, the priests emphasized: that was not enough, as there was a noticeable tendency among people for gradual forgetting of their heroes. That is why there were calls of higher clerical ranks to the parish clergy to erect monuments in honour of those who died for the freedom of Ukraine, which will have educational and demonstrative significance. It was emphasized that the installation of such monument in the form of a cross (oak or stone) near the church should be the responsibility of every pastor, and in the church itself on the wall it was recommended to place a memorial plaque with the names of the fallen (Маріян Р. Цурковський, о. Духовенство і культ наших поляглих борців. Нива. 1928. С. 242-246).

36 Забзалюк Д. Душпастирська служба... С. 43.

37 Про відзначення Різдва у сотнях УСС див. також: За волю України. С. 134-135.

38 Островерха М. Грозна калини... С. 70. 
and communion, and on the very feast of Resurrection he held a solemn Liturgy for the regiment lined up on the square ${ }^{39}$.

Undoubtedly, spiritual sermons, which were supposed to support the moral and fighting spirit of the soldiers, also acquired exceptional significance in the circumstances of war. For example, addressing the soldiers who went to the Italian front, Chaplain Dr. Andriy Ishchak ${ }^{40}$ stressed that their weapon in the fight against the enemy should be unshakable faith in God, love for their motherland and hope for a quick victory. «Neither for whim, nor for the desire to dominate and oppress other peoples, we are waging this difficult war, but ultimately for our own defense»-, said the priest ${ }^{41}$. "Go in the conviction that God's help is on your side, - he urged, - for you risk your lives for the right cause, for the happiness and peace that has been ripped from us and our families, in defense of the just rights that belong to us, our region and state $\rangle^{42}$. At the same time, the chaplains emphasized that Ukrainian soldiers were fighting for the historical right of Ukrainians to revive their statehood and were approaching this expected for centuries time. «As the disciples believed in the immortality of Christ, believe in the immortality of Ukraine, in its Resurrection!», priest Mykola Yizhak addressed Sich Riflemen in $1916^{43}$.

However, in the circumstances of constant trials and tribulations, illness, injury and death, often even the most inspired words, the greatest arguments became ineffective and powerless. Strengthening the fighting spirit of the army priest Dr. V. Laba called «the painful duty of a military chaplain». «The duty became especially painful at the end of the war, said the priest, - then the military resources were exhausted and the military chaplain had to tell the fatigued soldiers about loyalty, courage and endurance until victory. The military chaplain's voice was trembling in this kind of speech to the soldiers ${ }^{44}$.

During their stay at the front, the chaplains visited the soldiers on the battlefield, organizing services at the front line on a military altar prepared by the soldiers. Here is what the lieutenant of the USS regiment Roman Kupchynskyi told about the military chaplain of the Legion priest Yulian Fatsievych: «In March 1917 I went with our unit to the front near Berezhany. We were sent to the trenches near Kuropatnyky. We stood on the edge of the forest and there the priest often visited us. Sometimes he walked through the trenches, talked to the boys, and on Sunday in the woods he conducted the Divine Liturgy and

39 Островерха М. Грозна калини... С. 80-81.

40 Andriy Ishchak (1887-1941). He studied theology at the universities of Lviv and Innsbruck, where in 1914 he got his doctorate degree. Celibate. He was a chaplain during the First World War. In 1918 he was a prefect of the Lviv Theological Seminary. In 1919, after the UGA's retreat from Lviv, he served as a chaplain to wounded soldiers in the city's hospitals. From 1928 he taught at the Lviv Theological Academy. He was killed by the Bolsheviks in 1941 (Забанджала М. Лицарі духа... С. 64-65).

41 Іщак А., о. др. Проповідь до жовнїрів. (Перед відмаршом в поле). Нива. 1917. Ч. 2. С. 71. For the full text of the sermon, see appendix 3.

42 Там само. С. 72.

43 Їжак Микола, о. Проповідь виголошена дня 23. IV. 1916. До Укр. Сїч. Війська в селі Соснові пов. Підгаєцького. Нива. 1916. Ч. 5. Май. С. 296-297. For the full text of the sermon, see appendix 1.

44 Лаба В., о., др. Українські полеві духовники... С. 72. 
confessed ${ }^{45}$. In the conditions of threat to life and uncertainty of the future, these services evoked hitherto unknown experiences and emotions: "We listened to this Liturgy, the heart stood near God, and the larks filled the space with songs like incense, singing hymns to the Eternal. [...] These were some of the best Divine Services I have ever heard: Golgotha was in the glory of the sun, in the heart of a warrior, in the singing of a lark!» M. Ostroverkha, a rifleman, later wrote with great emotion ${ }^{46}$. Sincere dedication to their vocation prompted the clergy to look for additional ways to provide soldiers with spiritual and moral support, providing them with a sense of love, care and concern for them. For example, chaplain Yu. Fatsiyevych arranged personally for collecting of paskas (Ukrainian Easter bread) before Easter Day among the civilian population, and himself delivered the collected items to the front line on wagons and consecrated them during a solemn service ${ }^{47}$. Thanks to his efforts, in October 1917 the Sich Riflemen met Metropolitan Andrei Sheptytskyi, who consecrated the flag of the USS Legion and the monument to the deceased riflemen, attended the military march held on the occasion of his visit and a solemn concert ${ }^{48}$.

During the battle, the military chaplains were near their soldiers, often acting together with military doctors. They confessed the wounded, supported the soldiers in every possible way, buried the dead ${ }^{49}$, and compiled detailed lists of the dead. Actually thanks to the chaplains of the USS priests A. Pshepyurskyi and M. Yizhak we have received detailed lists of Sich soldiers who died in the battles on Mount Makivka $(1915)^{50}$, near the village of Potutory and on Mount Lysonya (August - September 1916) ${ }^{51}$.

Many curates (S. Bachynskyi, L. Harkavyi, V. Kizhak, O. Kovalskyi, V. Telishevskyi, P. Chavs) had a special duty to take care of the wounded soldiers in military hospitals ${ }^{52}$. Analyzing the organization of this sphere of pastoral service in the Austro-Hungarian army, the Ukrainian magazine «Nyva» in early 1917 stated that the Greek Catholic military were largely deprived of the ability to meet their religious needs. This resulted from the fact that only one Catholic curate could work in each major medical or sanitary facility, which had to provide for the spiritual needs of the soldiers of both Catholic rites, Western and Eastern, and in practice Roman Catholic priests predominated. «So, the Poles have jurisdiction over the Galician Ukrainians in hospitals, and the Hungarians have jurisdiction over the Hungarian Ukrainians, - the «Nyva» correspondent summed up. - The Ukrainian clergyman is completely excluded from the divisional hospital, and in the depths of the region there are only one here and there in the main reserve hospitals, e.g. in Lviv, Stryi, Vienna, Budapest, Innsbruck, Ljubljana ${ }^{53}$. Therefore, Ukrainian military priests were usually with military groups at the front. However, they were not everywhere there either. As we read in a letter

\footnotetext{
45 Духовники УГА... С. 200.

46 Островерха М. Грозна калини... С. 87.

47 Духовники УГА... С. 201.

48 За волю України... С. 435.

49 Духовники УГА... С. 162-163.

50 За волю України... С. 302-311.

51 Забзалюк Д. Душпастирська служба... С. 43.

52 Список українських католицьких капелянів... С. 299-302.

53 Стан військових духовників в Австро-Угорщині по конець вересня 1916 р. Нива. 1917. Ч. 1. С. $41-42$.
} 
from one of the soldiers to his pastor, priest Isidore Hlynskyi, he «often thought how is it to die without confession? Noone to cry for you. Nor to carry out the burial. They will just throw you into a pit like an animal and throw the ground on top. It is a pity to have what we've got. Our youth was wasted. [...] Dean, a year has passed since I heard the GreekCatholic liturgy, because we have noone to conduct it because we do not have Ukrainian priests here ${ }^{54}$. At the same time, M. Ostroverha recalled how, while being housed in an evacuated Galician village, the Slovak chaplain periodically conducted services in the local church in the Greek Catholic rite. Not only Galician Ukrainians, but also Slovaks and Ruthenians from Transcarpathia came to these Liturgies ${ }^{55}$.

The outbreak of the First World War was also the moment when Ukrainians, divided by the borders of the Austro-Hungarian and Russian Empires, came together on the battlefield. Under such extreme conditions took place their direct acquaintance, they got to know ideological views, traditions, beliefs of each other. Greek Catholic chaplains also contributed to this process. Thus, with the assistance of priest M. Yizhak in 1917 on the Russian front appeared the practice of fraternization of Ukrainian soldiers in opposing armies. Later, thanks to the ministry of his successor - priest Anatolyi Bazylevych, Ukrainians of the Dnipro region learned the beauty of the Greek Catholic rite, joining the services, which were regularly carried out by a military chaplain accompanied by a well-trained riflemen choir $^{56}$. At the same time, contemporaries have repeatedly noted that the efforts of Ukrainian chaplains, through their sacrificial pastoral and educational work managed to overcome prejudice and hostility towards Ukrainians among the peoples of the Austro-Hungarian Empire, which arose partly due to lack of reliable information. Ukrainians were portrayed as friendly to Russia, and therefore hostile to the Habsburg Empire ${ }^{57}$.

Being constantly with the military, the chaplains, of course, were exposed to the dangers of wartime: wounded, infected during epidemics, died. Many of them were captured by Russians or Italians (such as priest Joseph Ivanets (1883-1946), who returned from Russian captivity in $1922^{58}$, or Julian Bachynskyi (1885-1959), chaplain of the 35th Zolochiv Regiment, who survived both captivity - Italian and Russian, where he fell ill with typhus). It is noteworthy that even in this situation the priests did not leave their pastoral ministry. For example, priest R. Dobodych, I. Lebedovych and V. Mastsiukh, who became prisoners of the camp for Ukrainian prisoners of war in Cassino (Italy), cared about meeting the religious needs of prisoners, also trying to establish for them the activities of cultural and educational groups ${ }^{59}$.

To make up for the losses of the chaplains, the church authorities appealed to the parish clergy to enroll for the army ${ }^{60}$. According to priest I. Lebedovych, during the First World War 147 Ukrainian Greek Catholic priests passed through the duties of chaplains

54 Львівська національна наукова бібліотека ім. В. Стефаника НАН України. Відділ рукописів. Ф. 159 (Глинські). Спр. 62. Арк. 1 зв.-2.

55 Островерха М. Грозна калини... С. 82-83.

56 Забзалюк Д. Душпастирська служба... С. 43, 46.

57 Рудович І., о. Гонїм мраки тьмаві. Нива. 1916. 1 сїчня. С. 49-52. See also appendices 4 i 5.

58 Забанджала М. Лицарі духа... С. 63.

59 Забзалюк Д. Душпастирська служба... С. 38.

60 See in particular: Справа іменованя гр. кат. війскових куратів в резерві. Вістник Перемискої Enapxuї. 1917. Ч. XIII. C. 106. 
(permanent and reserve) $)^{61}$. For their service, all these pastors were awarded with honours of the Austro-Hungarian Empire, and some of them - even several ${ }^{62}$.

Prosopographic portrait of Ukrainian chaplains. The list compiled by M. Zabandzhala enabled us to form a general image of a Ukrainian military clergyman ${ }^{63}$. The list itself was a result of supplemented and clarified information provided by priest I. Lebedovych. However, the information presented in this list is quite heterogeneous: some biographies are very detailed (recorded years of life, social origin, level of education, marital status, place of pastoral ministry and facts of cultural and educational activities; described the chaplaincy during the war, participation in socio-political life of Ukrainians in the interwar and Soviet periods, pastoral service in the postwar period), while others are limited to a brief reference (years of life, the fact of being at the front and the place of pastoral ministry). To detail the prosoprographic portrait, we also used the data of the Lviv archdiocesan schematism for 1918.

Most military clergymen were born in the 1880 s, so they were $30-40$ years old at the time of the Great War ${ }^{64}$. Out of the 158 chaplains recorded by M. Zabandzhala, social status was noted only for 22 of them. The most numerous were people from clergy families - there were as many as $15^{65}$ of them, 4 were the sons of wealthy peasants and per one from families of a notary, a teacher and a militaryman. All of them, in accordance with the requirements of the time, got a thorough education, graduating from elementary school and high school, and later a four-year course of study in theological seminary, combined with lectures at the theological faculty of the university ${ }^{66}$. From the list of M. Zabandzhala we know about the place of study of 107 chaplains: 31 of them were graduates of Przemyśl $1^{67}$, 23 - Lviv and three - Stanislavska Greek Catholic Theological Seminary ${ }^{68}$. Dozens of future clergymen studied theology in European educational institutions: 10 - in theological seminary or theological faculty of the University of Innsbruck (Konstantyn Bogachevskyi, Porphyryi Bodnar, Mykola Didunyk, Yosyf Dobryanskyi, Andriy Ishchak, Petro Kashuba, Mylosh Levytskyi, Mykola Nahoryanskyi, Lev Skobelsky, Ignatius Tsegelskyi), 6 - in the seminary in Vienna (Lev Van, Kornylo Kuzyk, Mykola Nahoryanskyi, Lev Skobelskyi, Ivan Skorobohatyi, Teofil Tchaikovskyi), 2 - at theological Faculty of the University of

61 Список українських католицьких капелянів... С. 299-302.

62 Шематизм всего духовенства греко-католицької Львівської Митрополичої Архієпархії на рік 1918. Львів, 1918. С. 176.

63 Забанджала М. Лицарі духа...

64 Шематизм всего духовенства греко-католицької Львівської Митрополичої Архієпархії на рік 1918. С. 157-158.

65 The cases when sons from families of priests chose the path of pastoral ministry was still quite common at that time, but was already undergoing significant changes. (Колб Н. Роль жінки (матері/дружини) в житті греко-католицького парафіяльного духовенства в Галичині наприкінці XIX - на початку XX століття (на прикладі о. Ісидора Глинського). Galicja i jej dziedzictwo. Rzeszów, 2016. T. 24: Kobieta w Galicji. Nowoczesność i tradycja. S. 200).

${ }^{66}$ Глистюк Я. Генеральна духовна семінарія у Львові 1848-1914: інституційна та соціальна історія: дис. ... канд. іст. наук: 07.00.01 / Львівський національний університет імені Івана Франка. Львів, 2008. С. 39-40, 71-74, 129-152.

67 М. Ж. 3 історії гр.-кат. духовної семінарії в Перемишлі. Альманах українських богословів. Львів, 1923. С. 137-138.

68 І. Л., о. 3 історії Духовної Семінарії в Станіславові. Там само. С. 139. 
Vienna (Kasiyan Kunitskyi and Vasyl Mastsyukh), 4 - in Rome (Stefan Vorobets, Mykola Didunyk, Yosyf Dobryanskyi, Dmytro Koltun), and per one - at the University of Leuven (Belgium) (Emilian Gorchynskyi), the Theological Academy of Bologna (Italy) (Julian Grankivskyi), the Pontifical College of St. Josaphat (Rome) (Zenon Kalenyuk) and the Theological Seminary of Krakow (Emilian Kalenyuk) ${ }^{69}$.

Prior to military service, the vast majority of reserve Greek Catholic military chaplains were parish priests. However, among them there were those who previously had quite high positions in the GCC. Thus, priest. Porphyryi Bodnar (OSBM), in addition to serving in church, also worked at the Missionary Institute named after St. Josaphat in Buchach ${ }^{70}$. Eusebius Gorchynskyi was vice-rector of the Lviv Theological Seminary, in 1911 - a clerk of the metropolitan consistory ${ }^{71}$. Konstantyn Bohachevskyi worked as a prefect of Lviv Theological Seminary and a clerk of Lviv consistory ${ }^{72}$.

Chaplains became prisoners not only in Italian or Russian camps. Some of them ended up in the Thalerhof camp, where the Austrian authorities sent Galician Ukrainians of Russophile orientation ${ }^{73}$. Among them were Teofil Kachmaryk, Myron Koltonyuk, Teodor Savoyka, Kyrylo Tustanovskyi and Vasyl Mastsyukh (an active participant of Russophile movement in the interwar period, and from November 1934 - apostolic administrator for the Lemko region ${ }^{74}$ ).

A characteristic feature of military clergy was patriotism. Many of them supported the national liberation struggle of Ukrainians in Galicia in 1918-1919. The priesthood of the newly created UGA (Ukrainian Galician Army) was based on 17 priests who had returned from the fronts of the First World War ${ }^{75}$. Later, they became among those who defended national interests, showing political activity. In particular, members of one of the most influential Ukrainian parties in the Republic of Poland - the Ukrainian National Democratic Union - were Vasyl Brytskyi, Volodymyr Pellikh, Andriy Pschepyurskyi, Volodymyr Samotulka, and a member of the Ukrainian Military Organization and the Organization of Ukrainian Nationalists was Mykola Prytulyak ${ }^{76}$.

Many former chaplains lived until the 1960s and 1970s, thus living in several states: Austria-Hungary, the Republic of Poland, Germany, and the Soviet Union. While remaining faithful to their nation and combining service to their own people with pastoral work, these priests were often repressed by all of the foreign regimes. Zenon Kalenyuk (1887-1979), for example, was arrested in 1941 by the German authorities and then twice more by the

69 Забанджала М. Лицарі духа... С. 43.

70 Там само. С. 49

71 Там само. С. 56-57.

72 Там само. С. 47.

73 Orlevych I. Intellectual thought of the Galician Russofiles of the interwar period about the Thalerhof tragedy. Intellectuals and the First World War / ed. by T. Pudłocki, K. Ruszała. Kraków, 2018. P. 321-347.

74 Орлевич I. Русофільська течія на початку 1920-х років у Галичині. Галичина. Науковий $i$ культурно-просвітній краєзнавчий часопис / гол. ред. М. Кугутяк. Івано-Франківськ, 2013. Вип. 22-23. С. 200-209.

75 Забанджала М. Лицарі духа... С. 118.

76 Див.: Соляр I. Українське національно-демократичне об’єднання: перший період діяльності (1925-1928). Львів, 1995. 
Soviets (in 1948, for refusing to convert to Orthodoxy and ties with the Organization of Ukrainian Nationalists (OUN) and the Ukrainian Insurgent Army - UPA). and in 1974 - for the requirement to legalize the $\mathrm{UGCC}^{77}$ ). Repressive measures by the Polish authorities extended mainly to those chaplains who were members of the UGA, OUN and marked by anti-Polish speeches - Emilian Kalenyuk, Myron Kolotnyuk, Mykhailo Komarnytskyi, Yuriy Mentsitskyi, Mykhailo Paslavskyi, Myroslav Ripetskyi, Kyryl Tustanivskyi, Ivan Fedynskyi, Omelyan Tchaikivskyi, Theophilus Tchaikivskyi.

With the beginning of the Second World War, the western Ukrainian lands became part of the USSR. Since Eastern Galicia had the largest number of anti-Soviet armed underground, and its ideological base was considered by the Bolshevik authorities to be the Ukrainian Greek Catholic Church ${ }^{78}$, it was decided to liquidate this national spiritual structure by «reuniting» it with the Russian Orthodox Church (ROC) in Lviv at the so called «Cathedral» on March 8-10, 1946). The UGCC, its clergy and the faithful, were forced to go underground (including chaplains Anton Bazylevych, Mykola Bril, Vasyl Brutskyi, Stefan Vorobets, Zenon Kalenyuk, Hryhoriy Khrushch, and Ivan Tsehelskyi). However, some priests converted to Orthodoxy (Mykola Gentosh-Yanyshyn, Yulian Hrankivskyi, Ivan Yesyp, Yosyf Ilnytskyi, Roman Kalenyuk, Mykhailo Komarnytskyi). For most of them, it was a formal act - they continued to be in communion with their now catacomb Church. Thus, Julian Bachynskyi motivated his transition to the ROC by the fact that he sought to prevent the former Greek Catholic parishes of «Moscow popes» ${ }^{79}$. Many priests openly opposed to converting to the Orthodox faith by the communist regime, for which they were repressed. Among them were the chaplains of the First World War, in particular Adrian Zafiyovskyi (sentenced in 1946 to 10 years in prison ${ }^{80}$ ), as well as Vasyl Brytskyi, Mykola Bril, Stefan Vorobets, Ivan Hornyatkevych, Emilian Gorchynskyi, Volodymyr Demchuk, Yosyf Dobryanskyi, Petro Zhupanskyi, Kornylo Zahaykevych, Andrian Zafiyovskyi, Andriy Ishchak, Zenon Kalenyuk, Oleksandr Kovalskyi, Konstantyn Koziy, Vasyl Kulyk, Dmytro Panasevych, Mykhailo Prokurat, Yosyf Pshepyurskyi, Mykola Pyasetskyi, Ivan Tizhbir, Ivan Fedynskyi, Ilyariy Fenchynskyi, Ihnatiy Tsehelskyi, Stefan Yuzych. In total, out of 67 military clergy, about 25 were arrested and 15 emigrated abroad.

As we can see, the patriotism and high national consciousness of the chaplains determined their civic position throughout their lives. They joined the UGA, later became members of the most influential Ukrainian parties and organizations (the Ukrainian National Democratic Alliance, the Ukrainian Military Organization, the Organization of Ukrainian Nationalists, the Ukrainian Insurgent Army), were repressed by the German and Soviet regimes, were members of the Greek Catholic underground.

Conclusions. The outbreak of the First World War launched the mechanism of military pastoral ministry in the Austro-Hungarian Empire. Along with the current Greek Catholic chaplains, a reserve staff of military clergy was called to serve at the front. Also, responding

\footnotetext{
77 Забанджала М. Лицарі духа... С. 67.

78 Seе.: Стоцький Я. Українська Греко-Католицька Церква і релігійне становище Тернопільщини (1946-1989 рр.). Тернопіль, 2003; Гуркіна С. «Образ сили духу»: греко-католицьке духовенство Львівської архиєпархії після Другої світової війни і проблема персоніфікації релігійних переконань та ідентичности. Україна модерна. Київ; Львів, 2007. Ч. 11. С. 99-110.

79 Забанджала М. Лицарі духа... С. 47.

80 Там само. C. 62.
} 
to the needs of the army, the ranks of Ukrainian chaplains were voluntarily joined by parish pastors. During the war years, 158 Greek Catholic priests served in the Austrian army. According to statistics, these were mostly people aged 30-40 with higher education, stable civic position and national beliefs. In extremely difficult conditions of the war, Ukrainian military clergymen were with their soldiers: they conducted services, confessed, conducted educational and cultural activities, provided spiritual and moral support to the wounded, buried the dead and kept records of them. Many of these pastors had a high authority in the army. While at the front, military priests experienced all the hardships and trials of wartime, fell victim to epidemics, came under fire and were taken prisoners. Evidence of the courage of Ukrainian Greek Catholic chaplains was the fact that they were all awarded state awards.

\section{REFERENCES}

[B.a.]. (1916). Voienna statystyka hr.kat. viiskovykh kurativ do kintsia r. 1915. Nyva, 7-8, 426-427 [in Ukrainian].

[B.a.]. (1917). Sprava imenovania hr. kat. viiskovykh kurativ v rezervi. Visnyk Peremyskoi Eparkhii, XIII, 106 [in Ukrainian].

[B.a.]. (1918). Shematyzm vseho dukhovenstva hreko-katolytskoi Lvivskoi Mytropolychoi Apchiieparkhii na rik 1918. Lviv [in Ukrainian].

Curkovsi, M. R. (1928). Dukhovenstvo i kult nashykh poliahlykh bortsiv. Nyva, 7, 242-246 [in Ukrainian].

Hlystiuk, Ya. (2008). Heneralna dukhovna seminaria u Lvovi 1848-1914: instytutsiina ta sotsialna istoriia. [General Theological Seminary in Lviv 1848-1914: Institutional and Social History] (Candidate's thesis). Lviv [in Ukrainian].

Hurkina, S. (2007). «Obraz syly dukhu»: hreko-katolytske dukhovenstvo Lvivskoi arkhyeparkhii pislia Druhoi svitovoi viiny i problema personifikacii relihiinykh perekonan ta identychnosty. Ukraina moderna, 11, 99-110 [in Ukrainian].

Ishchak, A., o. dr. (1917). Propovid do zhovniriv (Pered vidmarshom v pole). Nyva, 2, 70-73 [in Ukrainian].

Kis, N. (2018). Pamiat ta identychnist ukrainskykh hreko-katolykiv. Pro dzherela istorychnoi polityky UHKTs. Lviv [in Ukrainian].

Kolb, N. (2015). "Z Bohom za Tserkvu i vitchyznu»: hreko-katolytske parafiialne dukhovenstvo v Halychyni u 90-kh rokakh XIX stolittia. Zhovkva: Misioner [in Ukrainian].

Kolb, N. (2016). Rol zhinky (materi/druzhyny) v zhytti hreko-katolytskoho parafiialnoho dukhovenstva v Halychyni naprykintsi XIX - na pochatku XX stolittia (na prykladi o. Isydora Hlynskoho). Galicja i jej dziedzictwo, 24, 199-213 [in Ukrainian].

Kolb, N. (2017). «...Vitcevi nichoho ne ye chuzhe, shcho syniv, ditei yeho obkhodyt»: vnesok hreko-katolytskoho dukhovenstva u formuvannia zasad hromadianskoho suspilstva v Halyczyni (kinats XIX stolittia). In I. Soliar (Ed.), Vzaiemodiia instytucii derzhavy $i$ hromadianskoho suspilstva v Ukraini: zakhidni zemli (kinets XIX-pochatok XXI st.) (pp. 493-512). Lviv [in Ukranian].

Kolb, N. (2018). The Great War in the Light of Documents and Correspondence of the Galician Greek Catholic Parish Priest Isydor Hlynskyi. In T. Pudłocki \& K. Ruszała (Eds.), Intellectuals and the First World War (pp. 185-200). Kraków [in English]. 
L., o. (1923). Z istorii Dukhovnoi Seminarii v Stanislavovi. Almanakh ukrainskykh bohosloviv, 139-140 [in Ukrainian].

Laba, V., o, dr. (1963). Ukrainski polevi dukhovnyky nashykh pamiatnykh dniv. In I. Lebedovych, Polevi duchovnyky Ukrainskoi Halytskoi Armii. U 45-richchia uchasty u vyzvolnykh zmahanniakh. (Materialy do istorii) (p. 71). Winnipeg [in Ukrainian].

Lazarovych, M. (2016). Lehion Ukrainskykh sichovykh striltsiv: formuvannia, ideia, borotba. Ternopil [in Ukrainian].

Lebedovych, I. (1963). Polevi duchovnyky Ukrainskoi Halytskoi Armii. U 45-richchia uchasty u vyzvolnykh zmahanniakh. (Materialy do istorii). Winnipeg [in Ukrainian].

Lozynskyi, A. (2017). Viiskove dukhovenstvo v roky Pershoi svitovoi viiny. Ukrainoznavstvo, 1-2, 62-63 [in Ukrainian].

M. Zh. (1923). Z istorii hr.-kat. dukhovnoi seminarii v Peremyshli. Almanakh ukrainskykh bohosloviv, 137-138 [in Ukrainian].

Orlevych, I. (2018). Intellectual thought of the Galician Russofiles of the interwar period about the Thalerhof tragedy. In T. Pudłocki, \& K. Ruszała (Eds.), Intellectuals and the First World War (pp. 321-347). Krakow [in Ukrainian].

Ostroverkha, M. (1962). Hrozna kalyny v Ukrainskych Sichovych Stilciv. New York [in Ukrainian].

Predka, S. (2016). Kapelany ukrainskykh zbroinykh formuvan v Halychyni 19141919 rr. (za materialamy spohadiv poliovykh dukhivnykiv). Istoriia relihii $v$ Ukraini. Naukovyi shchorichnyk, 1, 472-482 [in Ukrainian].

Ripeckyi, S. (Ed.). (1967). Za voliu Ukrainy. Istorychnyi zbirnyk USS. 1914-1964. New York [in Ukrainian].

Rudovych, I., o. (1916, Sichen 1). Honim mraky tmavi. Nyva, 1, 49-52 [in Ukrainian].

Shakh, S. (1963). Vstupne slovo. In I. Lebedovych, Polevi duchovnyky Ukrainskoi Halytskoi Armii. U 45-richchia uchasty u vyzvolnykh zmahanniakh. (Materialy do istorii) (p. 16). Winnipeg [in Ukrainian].

Soliar, I. (1995). Ukrainske natsionalno-demokratychne obiednannia: pershyi period diialnosti (1925-1928). Lviv [in Ukrainian].

Stotskyi, Ya. (2003). Ukrainska Hreko-Katolytska Tserkva i relihiine stanovyshche Ternopilshchyny (1946-1989 rr.). Ternopil [in Ukrainian].

Velykyi, R. (2016). Blahodiina ta dukhowna opika viiskovosluzhbovtsiv v roky Pershoi svitovoi viiny. Proceedings of the IX International Conference: Khrystyianska sakralna tradycia: vira, dukhovnist, mystetstvo, Lviv, 24 lystopada 2016. Lviv [in Ukrainian].

Yizhak, M., o. (1916, Traven). Propovid vyholoshena dnia 23.IV.1916. do Ukr. Sich. Viiska v seli Sosnovi pov. Pidhaietskoho. Nyva, 5, 296-297 [in Ukrainian].

Zabandzhala, M. (2018). Lytsari dukha. Viiskove kapelanstvo UHKTs XIX-XX stolit u biohrafiiakh. Lviv [in Ukrainian].

Zabzaliuk, D. (2012). Dushpastyrska sluzhba ukrainskykh viiskovykh formacii pershoi polovyny XX st. Lviv [in Ukrainian].

Orlevych, I. (2013). Rusofilska techiia na pochatku 1920-kh rokiv u Halychyni. Halychyna. Naukovyi i kulturno-prosvitnii kraieznavchyi chasopys, 22-23, 200-209 [in English]. 
Наталія КОЛБ

кандидат історичних наук старший науковий співробітник відділу нової історії України Інституту українознавства ім. І. Крип'якевича НАН України науковий співробітник Інституту релігієзнавства філії Львівського музею історії релігії ORCID: https://orcid.org/0000-0003-4449-1991 e-mail: nata_kolb@ukr.net

Ірина ОРЛЕВИЧ

кандидат історичних наук завідувач відділу нової історії України Інституту українознавства ім. І. Крип'якевича НАН України науковий співробітник Інституту релігієзнавства філії Львівського музею історії релігії ORCID: https://orcid.org/0000-0002-7530-9833 e-mail: i.orlevych@gmail.com

\section{ПРОСОПОГРАФІЧНИЙ ПОРТРЕТ УКРАЇНСЬКОГО ГРЕКО-КАТОЛИЦЬ- КОГО КАПЕЛАНСТВА В РОКИ ПЕРШОЇ СВІТОВОЇ ВІЙНИ}

Окреслено історію формування та функціонування інституту капеланства в ГрекоКатолицькій Церкві в період входження Галичини до Австро-Угорської імперії. Зокрема означено систему підпорядкування капеланів, їхню чисельність, обов'язки, позицію в ієрархічній структурі ГКЦ. Показано завдання й реалії служіння польових духівників із вибухом Першої світової війни. Наголошено, що до обов'язків капеланів входили: відправа богослужінь в місцях постійної і тимчасової дислокації частин, сповідь воїнів перед боями, культурно-освітня робота з ними, опіка над хворими й пораненими у фронтових лазаретах і шпиталях, організація поховання загиблих та відправа панахид, ведення відповідних метричних книг та реєстрація військових поховань. На конкретних прикладах показано звитягу і жертовність українських капеланів. Висвітлено значення їхнього служіння для підтримки морального, бойового, національно-патріотичного духу вояків, для задоволення гострої потреби солдат у молитві та розраді, в налагодженні комунікації з командуванням в обставинах перебування в чужому іномовному оточенні. Окремі капелани, опинившись у таборах для військовополонених, виконували душпастирські послуги для своїх співвітчизників.

Більша частина капеланів Першої світової війни підтримала національно-визвольні змагання українців, дожила до радянського періоду, пробувши під владою трьох іноземних держав: Австро-Угорщини, II Речі Посполитої та Радянського Союзу. У всі ці періоди характерною рисою для більшості з них залишалася вірність своїй Церкві й народові.

Статтю доповнено додатками, що містять тексти проповідей капеланів, уривки зі звітів, інформацію з тогочасної священницької преси.

Ключові слова: Галичина, Греко-Католицька Церква, Перша світова війна, українські капелани, душпастирське служіння, культурно-освітня діяльність, просопографічний портрет. 
о. Микола Їжак

\section{Додаток 1}

u.i.к. полевий курат У. С. С.

Проповідь виголошена дня 23. IV. 1916. До Укр. Сїч. Війська в селі Соснові пов. Підгаєцького

Христос воскрес!

Нечувана, непонятна подїя в свїті сталась. Христа в могилу зложили, тяжким привалили каменем. Христос, Пан житя і смерти, що одним словом хорим здоровля, житя мертвим вертав, - Сам у могилі спочив!

Зраділи вороги..., душею зраділи! Та не на довго! Настав день третий, - недїля, «Воскресенїя день!» В часї, коли ще всї вороги Його солодким спали сном і о побіді мріли, - Христос воскрес!

Нерозривне пасмо терпінь та лихолїття України! Терпіла в княжій добі із-за домашньої незгоди князїв, терпіла із-за нападів Печенїгів та Татар; котились за правду і волю голови козацькі, «шматували», «рознесли, розірвали Україну і розпняли царі московські і кровю нашою собак поїли!»

Прийшла Голгофта, - війна отся! Страшною бурею звалилась російська навала на нашу землю, горіли села за селами... а кров лилась, землю зливала! До Карпат дійшов ворог, тих наших синїх гір, та прапор побіди заткнув. I як колись фарисеї Христа на дерево прибивши, - зрадїли й наші вороги і над українським народом похорон справляли!

«Оковано, омурано, багряницями закрито і розпятієм добито!»

Не добито!

Воскресла батьківська слава, з могил широких піднялась, ожила в вас! Ви, коштом власного життя розярили потахаючу ватру, роздмухали на ново!

І потекли рідньої, «живої крови чистої, святої», кріваві ріки!

Сотки-тисячі гинули з нас як в австрійських, так і наших стрілецьких рядах, щоб лиш «Вона», - Україна, - не вмерла! Вирвалось з сердець розпуки слово: «Ненько», та до житя Її з важкого сну вернуло, імя Іїі неначе молитвою стало!

Честь вам і слава борцї народні за це! А в нїй, у чести тій хай буде Вам найвисша на землї заплата..., заплата за посвяту ріднї, матери і сестри, жінки і нареченої, за безсонні ночі і в голодї перебуті днї, за біль і кров!

Та не конець ще! Сїм повітів жде Вас, сизії Орлята, вижидає волї.

Зявивсь Ісус Хр. по своїм воскресеню ученикам та сказав «Мир вам!»

Тож і Ви, воїни хоробрі, Стрільцї Січовії рук ще не складайте. А коли пора настане, всї як один за кріс хватайте, вороженьків наших «облавою пріть», та другим покажіте, як серед куль ворожих стояти треба. Ідіть сміло в перед на врага, щоб родинам нашим правдивий мир принести.

«Або смерть, або побіда,

Се наш оклик боєвий!...

До відважних світ належить!»

Як вірили ученики в безсмертність Христа, вірте в безсмертність НенькиУкраїни, в Ії̈ Воскресення!

Прийде пора, настане день, в котрім зникнуть вороженьки, «яко таєт воск от лица огня» а ми «возрадуєм ся і возвеселим ся в онь!» 


Прийде пора,
а оживуть степи озера
і не верстовії
а вольнії широкії
скрізь шляхи святі простелють ся, прийде пора, i-
воскресне Україна
світ правди засвітить,
і помолять ся на волї
невольничі дїти!...

Нива. 1916. Ч. 5. Май. С. 296-297.

\section{Додаток 2}

о. Д-р Андрій Іщак

\section{Перед панахидою за поляглих Укр. Сїч. Стрільцїв. (Проповідь)}

Больши сея любви никто же иматъ, да кто душу свою положитъза други своя! (Ів.15., 13.).

Ті слова св. Письма приходять менї Др. Бр. на думку, коли стаю перед численним збором вірних в тій божій церкві, щоби віддати почесть памяти поляглих Сїчових Стрільцїв. Бо чимже, як словами божими відозвати ся треба до христіяньского серця в так поважній хвили? Що сильнїйше ділає на душу вірних, як не слово боже, про котре

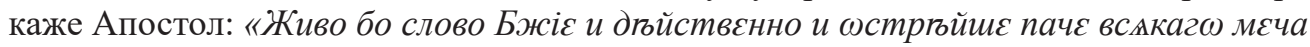

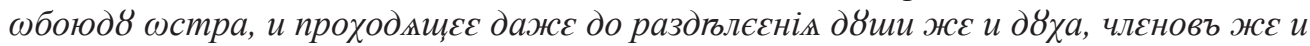
мозговъ» (Евр. 4., 12.). Сама повага хвилї, сам побожний настрій численно зібраних і дошки хоть лише провізоричні сеї святині і серед неї хрест чорний прикрашений рушниками а уставлений на сумну память наших Сїчових героїв наклонює нас до сего, щоби ми від слова божого зачали сей сумний обряд.

3 посеред веселих і сумних подій за час дволїтної вже війни, з посеред кровавих переживань нашого народа перед московським і в часї московського наїзду впливає на поверхню нашої свідомости донеслий факт покликаня до житя нової інституції У. С. С. На поклик Головної Народної Ради у Львові завязала ся в осени 1914 р. зараз по виповідженю війни нова органїзація Укр. Сїч. Стрільцїв. Сотки нашої молодїжи як інтелїгентної, так і свідомої сїльської спішили зі всїх сторін краю, щоби вписати ся в ряди У. С. С. Покидували вони свій батьківський дім, покидували турботи буденного життя, а піднимали ся за велике дїло. Крівавий протест проти відвічного нашого ворога, Москви, що закував 30 мілїоновий український нарід над Днїпром, Доном і Бугом в кайдани неволї і сї кайдани хотїв також і нам Українцям над Днїстром закинути на ноги, жадоба відплати за вікову неволю загоріла в молодих серцях. Пішли вони на тернисту дорогу боротьби з перемагаючим чисельно ворогом.

Коли видїло ся, як сей цвіт нашого народа, сї молоді орли злїтали до Львова, щоби звідси відступити на полудне, хотїло ся кликнути до них словами пророка Ісаї: 
«Оукртьпте сл сынове Венжминови посредг Іер8салима, возтр8битв тр8бою и надъ

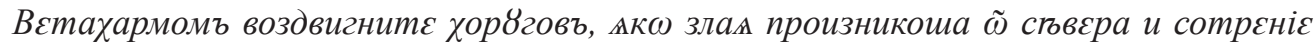
вєлико бывавтъ» (I. 6., 1.). Укріпіть ся сили українського народа серед наших старинних городів Льва, Галича і Перемишля, затрубіть в трубу і піднесїть над ними хоругов, бо нещастє надходить 3 півночи і буде великий бій... Але не відразу так судило ся. Перед переважаючим ворогом треба було відступити в Карпати, тут укріпляти ся через ціїлу зиму і доперва на веснї прийшло ся розвинути побідну хоругов, насамперед над Стриєм, потім над Перемишлем, Львовом і Галичом. В Карпатах зачинає ся терниста дорога, повна трудів і кровавих змагань, засїяна кістками і полята горячою кровю наших Сїчових героїв, яка веде остаточно до побіди.

Є се час проби для Укр. Сїчових Стрільцїв і час терпіня для цїлого українського народа.

Бо хто з нас, Др. Бр., не зазнав терпіня в часї російського наїзду на Галичину? Старий чи молодий, на становищи, чи без становища, інтелїгент чи селянин, всї однако терпіли. Терпіла церков, терпів нарід, терпіла власть духовна, запродувана $\mathrm{i}$ зраджувана тими, що від нас вийшли, але не були від нас - як каже євангелист Іван -

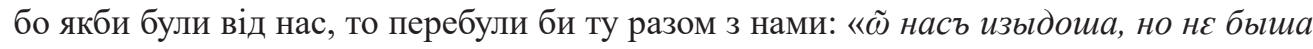

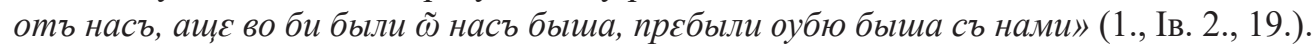
Терпіли врештї одиницї без жадної власти і сили. Де найспокійнійший чоловік улягав закидови шпіонажі длятого, що не признавав себе «русским», але отверто казав, що $є$ Українцем - де за «мазепинство» вивезено тисячі на Сибір - де не пошановано найвисшої церковної власти в особі нашого Митрополита, але засуджено його на муки в казаматах Курска - де і другого владику в Перемишли мучено трусами і приневолювано до зломаня присяги вірности католицькій церкві і австрійському цїсареви, доки не приспішено в той спосіб його смерти - де найвідважніший мущина тремтїв перед полїцайського нагайкою - де найспокійнійша жінка не могла вийти свобідно на улицю, щоби не наразити своєї чести на сором - де таке і подібне дїяло ся - там було терпінє, там була мука. I як би на глум, називали себе північні наїздники освободителями. Певне... Освободили вони насамперед панські шпіхлїрі зі збіжа, потім і селянина освободили з послїдної корови, врештї брали ся освободжувати у неодного душу з тїла. Неодин старий батько родини згинув від російських побоїв на форшпанї, неодна стара мати пішла гризти землю з жалю за своїми синами, неодна молода жінка збожеволїла з розпуки, що Москалі все спалили або зрабували та не буде чим дрібних дїтий виживити. Сей смуток, се терпінє виспівала народна пісня отсими словами:

Возьми мати піску жменю,

Посїй його на каменю;

Як той пісок з землї зійде,

Тогди син твій з війни прийде.

То був час загального терпіня, загального пригнобленя і упадку духа. По капітуляції Перемишля, рік тому назад, темні духи ликували, а пригноблені матери плакали за своїми синами, яких не сподївали ся вже ніколи побачити.

Однак день радости зближав ся скорше, нїж того можна було надїяти ся. Зближав

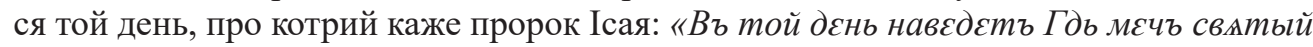
и великій и кргпкій на драконта змін л8кавагш и оубгвть драконта» (Ів. 27., 1.). I приспішили той день радости наші Сїчові Стрільцї. На Маківцї і тухольських горах, радо ішли до штурму і клали свої голови за рідний край; за свободу наших 
поневолених родин, за лїпшу долю братів, що очікували їх приходу. Відомі були їм всї насильства російського ряду, всї безправства царської армії на нашій земли і нїчого так не бажали для себе, як смерти в оборонї прав свого народа. Тому ішли так неустрашимо до бою, що з сотки вертало нераз лиш 20 назад. «Большє сея любви никтоже имать, да кто д8ш8 свою положить за др8ги свож» (Тим. 5., 18.), каже Христос. Нема більшої любви над тоту, коли хто віддає житє своє за своїх приятелїв. А таку власне надзвичайну любов виявили У. С. Стрільцї для свого народа. Для свободи того українського народа, для приверненя йому прав в конституційній державі Габсбургів, клали вони на жертвенник своє молоде житє. Божественний Спаситель вимагав від своїх учеників досконалости через се, що казав їм для себе і своєї науки

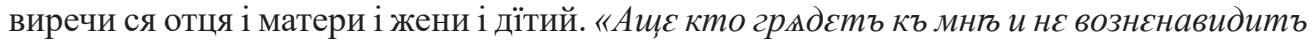

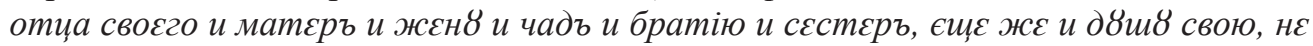
можстъ быти мой оучвникъ» (Лук. 14., 26). За сю апостольську посвяту, за се велике самовідреченє обіцяє Христос своїм ученикам і їх наслідникам надгороду вже на тім світї і понадто надгороду вічну на другім світї. «Аминь, аминь глаголю вамъ: никтоже єсть, ижс оставиль єсть домь, или братію, или сестры, или отцуа, или матврь, или

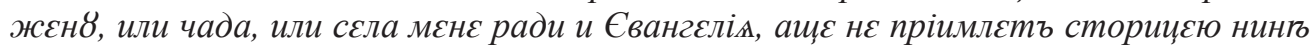
въ время сіє домовъ и братій и сествръ, и шиа и чадъ и сель ко изгнаніи и въ въкъ грдд8щій животъ въчныйџ (Мар. 10, 29. сл.). А якоїж надгороди мають очікувати від української суспільности наші добровольцї, які також полишили свої доми, своїх родичів і братів і сестер, а вибрали тяжку боротьбу за вітчизну? І що більше! Не лише покинули на якийсь час У. С. С. свою рідню, але сотки з них покинуло іiї навіки, кладучи ся до вічного сну на стоках Карпат і на рівнинах Подїля, а другі сотки стали досмертними калїками, нїчим непридатними для своїх родин. Якої надгороди мають очікувати одні і другі? Перші, що лягли сном покійних, не хотять жадної надгороди, лише мають одне бажанє, щоби їх згадувала з вдячностю українська суспільність, як борцїв за волю і щоби переказала їх геройську смерть потомности.

Тому ми сповнюючи се бажанє сходимо ся тут нинї, щоби прилюдно помянути наших поляглих героїв. Струпішіло їх тїло, кости їх зісхли, надїя на кращу будучність завмерла в їх серци, бо вони убиті. Зза гроба неначе відзивають ся вони до нас словами пророка Єзикиїла: «С8ұи быма кости наша, оубієни быхом» (Єзек. 37., 11.). А ми на се повинні відповісти рівнож словами пророка: «Се азъ отврз8 гробы ваша $и$

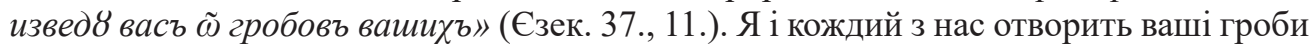
і виведе вас звідтам, щоби пам'ять ваша жила між нами, коли ви вже не жиєте.

А другі, що лишили ся калїками, але як і перші дали доказ великої любови для українського народа, тої любови, що гнала їх рівнож на житє і смерть проти ворога, ті другі - якої надгороди мають очікувати від української суспільности? Вони суть між живими і про них треба тямити, як про живі жертви війни. «Вола молотмща нє обротиии и достоинъ єсть дълатєль мзди свовя» (Тим. 5., 18.), каже ся в св. Письмі (Волови, що молотить, не обвяжеш рота і варта робітник своєї нагороди). Треба забезпечити їх житє, треба тепер вже постарати ся, щоби мали що їсти. Бо квестія хлїба є нинї так дуже актуальна - нинї, коли дає ся відчувати недобір (не кажу брак) поживи. Зі спокійною совістию сказати можем, що не були ми глухими, коли віднїс ся до нас стрілецький комітет, щоби ми зібрали на приют У. С. С. жертви в натурі. Стрілиска і околиця дали доказ своєї жертволюбивости. І нинї не змалїє наша щедролюбивість, але поплинуть щедрі датки на наш Сїчовий Приют, на ранених Укр. Інвалїдів, про котрих сердечно згадуєм. 
Наконець і про третих треба сказати, про тих У. С. Стрільцїв, що живі і здорові стоять в поли і наставляють свої груди на ворожі кулї. До них відзиваєм ся словами

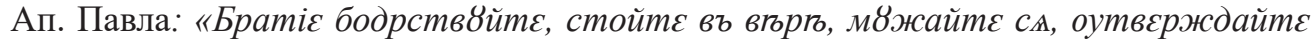
сж». Братя, будьте бодрими на дусї, стійте в вірі і один другого піддержуйте в переконаню, що недалекий вже день, коли ворог буде присмирений: «Дєнь бо Гда Саваота на всякого досадитвля горделиваго, на високаго и вєликаго и смирить сл» (Iс. 2, 12). I доперва по тім дни присмиреня північного ворога наступить мир. Доперва тодї сповнять ся слова пророчі: «И разк8ють мечи своя на орала і копія своя на серпи и не б8д8ть втом8 ратовать сж» (Iс. 2., 5.).

Амінь.

Нива. 1916. Ч. 5. Май. С. 297-301.

\section{Додаток 3}

о. Др Андрій Іщзак

\section{Проповідь до жовнїрів. (Перед відмаршом в поле) \\ Оболците са въ броню въры и любве и шлємъ оупованіћ. (І Сол. 5., 8.).}

Др. Бр.! Зібрали ся ви нинї тут численно, щоби в послїдне перед відходом в поле вислухати Сл. Божої, щоби упросити в Бога ласки на далеку дорогу. За пару хвиль зложите також публичну присягу вірности найвисшому нашому Монархови, що хоробро будете боронити держави і краю перед ворогом та повинувати ся будете розказам вашої старшини. В таку хвилю чую ся і я зобовязаним промовити до вас словом божим. Бо слово боже іменно має після слів Апостола сю велику силу, що доходить до найглубших комірок людського серця неначе обосїчний меч (Евр. 4, 12). Не що инше, як слово боже має сю високу власть, що підносить духа і утримує на вижинї своєї задачі.

Тому коли розходить ся нинї о піднесенє духа в нашім полку, нехай сего доконає слово Боже.

Жовнїри! Крім відваги, крім завзятости і витревалости, крім дисціплїни і технїчно удосконаленої збруї, потрібує армія передовсїм духа, щоби успішно борола ся 3 ворогом. Тому смію кликнути до вас за Апостолом: Возьміть на себе єще збрую душевну! Оболците ся въ броню въры и любве и шлємъ оупованіл. Уберіть ся єще в збрую віри $і$ любови і приодягнїть шолом надіï!

Най у всїх ваших походах і у всїх ваших змаганях з ворогом присвічує вам сильна віра, що остаточно побідите ворога. Сильна віра в остаточну побіду най все оживляє вашу грудь, бо стаєте перед ворогом в оборонї слушної і святої справи.

Станете на полудневім фронтї перед віроломним союзником Італїєю, що підло зрадила приятельський союз заключений з Австрією і Нїмеччиною. Погадайте собі, що неодин з вас по всїх трудах і невигодах, по цїлорічних кровавих змаганях проти північного ворога, Росіянина, бувби вже спокійно заживав мира в дома між своєю 
родиною, наколиби не віроломна Італїя. Якраз тодї, коли північний ворог був цїлковито розбитий, коли по погромі під Горлицями гнали єго наші хоробрі війська аж за Бересть литовський на пинські багна і за Буг та за Стрипу в Галичинї, якраз тодї віроломний союзник Італїя зачав грозити нам ударом з заду від полудня. I коли би не було треба роздїлювати наші сили звернені проти Росіян, щоби боронити ся з полудня, то певно, що були би наші війська зимували минулу зиму в Київі і в Петроградї а на веснї були би вернули по заключенім мирі до дому. Але той ворог полудневий зменшив наш розмах, з яким ми перли Росіян, проволїк війну, віддалив надїю мира, виставив родину неодного нашого жовнїра на нову руїну і нову недолю під Росіянином. Поступила Італїя неначе той негідний сусїд, що видить, як горить хата єго поміжника, але не поспішить на ратунок. Що гірше, він заложить руки в кишенї і зачне говорити: «Що даси менї, сусїде, за се, що я буду лиш спокійно дивити ся на твою пожежу а не піду з другого боку підпалити твого обійстя?» А в кінци по довгих короводах таки підлий сусїд підложить власною рукою огонь $з$ другого боку. Так як той сусїд палїй поступила Італїя.

Длятого кілько разів прийде вам бороти ся з полудневим ворогом, будьте переконані, що єго віроломство мусить бути покаране. Майте кріпку віру, що правда віднесе побіду над неправдою, а справедливість над несправедливостию. Витревайте в вірі на остаточну побіду, будьте мужні, тримайте ся на своїх становищах проти

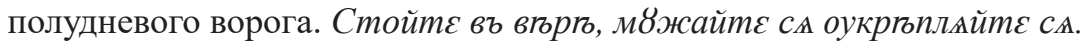

Другою зброєю духовною крім віри є любов. Не о тій любови є бесїда нинї, котра називаєть ся головною христіянською чеснотою, але о тій любови, яка тепер одушевляти повинна грудь кождого жовнїра, о любови до вітчини. Любов до вітчини наказує нам боронити свого краю і своєї монархії перед ворогом. Не для примхи, не для заборчих інтересів, не для охоти панованя над другими і гнобленя других народів провадимо ми сю тяжку війну, але для власної оборони і з конечности. Коли перша Сербія розпалила пожежу европейської війни і витягнула братоубійчу руку на представителя нашої держави, престолонаслідника Франца Фердинанда, то не що инше, як конечність вимагала жадати сатисфакції за сей злочин. Почутє справедливого обуреня повставало в серци кождого горожанина австрійської держави - всї знали і розуміли, що війна з Сербією є неминуча, що покараний мусить бути злочин. А дальше, коли Росія нібито беручи в опіку славянські народи - а в самій річи для рабунку і нищеня нашого народа в Галичині, проголосила війну, то рівнож конечність вимагала, щоби ми боронили ся проти північного ворога. Від Залозець аж до Перемишля і Ніска боронили ви своєї землі. Через цїлий рік зносили ви воєнні труди і невигоди, доки не відкинули ворога далеко поза границі нашого краю і нашої держави. Нехайжеж та сама любов вітчини, що позволила вам поховати північного ворога, оживляє вашу грудь у всїх ваших кровавих змаганях проти полудневого неприятеля. Оукргопитє сA сынове Венаминови посредг Іер8салима, возтр8бите тр8бою и надъ Ветахармомъ воздвигнитє хор8говъ (Із. 6. 1.). Як укріпляли ся ви, сини українського народа, під Красним, Яновом, Перемишлем і Ніском, так укріпляйте ся на ваших становищах на полудни над Ізонцо, Манфальконе, Добердо, на Карсті і в долині Віппах, піднесїть високо вашу хоругов і ідїть до остаточної побіди.

А третя чеснота, яка присвічувати повинна жовнїрови, поставленому на сторожи краю - се надія «шлемъ оупованім».

Серед найтяжших трудів і невигод будьте витревалі. Ідїть все вперед в тій надії, що по вашій сторонї є поміч божа, бо наставляєте свою грудь за слушну справу, за 
щастє і спокій, який видерто нам і нашим родинам, в оборонї справедливих прав, які належать ся нам, нашому краєви і державі. Тому будьте переконані, що прийде день божої справедливости і боожого суду над кождим ворогом, що розпалив сю велику европейську війну між супокійними народами. День кари божої на кождого гнобителя, на кождого наїздника і розбійника справедливости і права і він буде присмирений. Дєнь во Гда Саваота на всжкого горделиваго и досадитєлм на високаго и вєликаго и смирить ся. (Із. 27.1). Амінь.

Нива. 1917. Ч. 2. За лютий. С. 70-73.

\section{Додаток 4}

Уривок зі звіту о. декана Данила Бодревича, пароха Порохника, про його працю в Сомбатгельській епархії в північнозахідній Угорщині за час його семимісячного перебування в Сомбатгелі

Коли я приїхав з родиною до Сомбатгелї, тамошний латинський епископ Іван гр. Мікеш приняв мене вельми ласкаво і прихильно. [...] дав мені власть відправляти Службу Божу і слухати сповіди в цїлій своїй епархії, з чого користав я аж до свого виїзду до Галичини. Як раз в тім часї було стаціонованих в Сомбатгелї і в тамошнім комітатї богато наших жовнірїв головно з ярославського повіту, які не мали капеляна. Епископ дуже зрадів мому приїздови і заявив: «Добре, що судьба принесла вас тут, можете богато здїлати для своїх земляків-жовнїрів, яким я і мій клир, не вміючи по українськи, не можемо нести духовної помочи». Я взяв ся радо до працї, та сам оден не міг дати собі раду. Тому поручив епископ зладити і випечатати помічну книжочку до сповіди: «Confessarius militum», в якій поміщено найважнійші питаня при сповіди у всїх мовах австро-угорських народів, а також і в українській, але мадярською правописию.

Богослуженя для жовнїрів відправлялись в місцевих католицьких костелах. Жовніри приходили дуже радо і часто, а їх побожність і краса нашого богослуженя робили дуже корисне вражінє на тамошне населенє. Годї не піднести се, що наші жовнїри все маркували свій католицизм і приналежність до греко католицького обряду і не заходили до протестантских зборів.

Случалось, що придїлені до угорських полків і хорі по шпиталях жахались признати ся до української народности. Більшість 3 них були се одиницї національно свідомі, та лиш спомин про події в серпни 1914 р. спонукував їх промовчувати свою народність; они звали себе Галичанами. По кількоразовій появі свого священика і ті люди зовсїм осьмілювались і признавались до своєї народности.

По селах навкруги Сомбатгелю був стаціонований полк уланів майже виключно Українців. Тамошні мадярські душпастирі старались обслужити наших жовнїрів, а зокрема виявив богато спочуваня нашим землякам о. Ференц Рофош, парох в Бік. В сїй місцевости був великий шпиталь і стояло 300 наших уланів. О. Рофош не міг розмовитись 3 нашими хорими і тому поїхав до сомбатгельського епископа, щоби постарав ся о священика Українця. Епископ поручив мене. На запросини пароха був я кілька разів в тамошнім шпитали, висповідав всїх жовнїрів, відправляв Служби Божі в парохіяльнім костелї, а жовнїри співали дуже гарно.

За почином о. Рофоша інтелїгенція з Біку завязала самаританський кружок, який помагав хорим жовнїрам. [...] Коли довідав ся п. Красїцкий, майор уланів в Чепрег, 
що я був в Біку, запросив мене на сповідь уланів в Чепрег. Дуже радо поїхав я до того села, бо там було більше як 600 наших людий. Сидїв я там більше як тиждень, заки всїх висповідав і обслужив. Майор і весь офіцирський корпус ішли менї на руку, in corpore приходили на богослуженя, що приманювало і місцеве населенє, яке не могло налюбуватись нашим гарним співом церковним.

Рівнож радо приймали мене в Льочманд, Дяльока і других місцевостях.

На порученє сомбатгельського епископа запросили мене на духовну працю в Шарвар (Sarvar), де було богато наших ополченцїв. До Шарвар виїздив я кілька разів, за кождим разом сидїв там довший час, сповідав, відправляв богослуженя, відвідував жовнїрів, потїшав їх, та дїлив ся з ними скупими вістями з рідного краю, які чув від наших людий, або вичитав в часописях. Праця ту була приємна, бо місцевий парох о. Кеберль і єго о. сотрудник в проповідях поучили своїх вірних про гр. кат. церков, про Україну і Українців, про наші релїгійні і національні змаганя. На наших богослуженях костел був заповнений не лиш військом, але в більшости місцевим населенєм.

Скитаючись по західній Угорщинї мав я нагоду познакомитись 3 многими чужинцями і освідомити їх про наші релїгійні і національні змаганя та про наш нарід. Велику прислугу зробила брошура проф. Дра Ст. Рудницького «Ukraina», видана в мадярській мові. Я дістав даром 20 примірників від нашої репрезентації і роздав їх найвпливовійшим мадярським личностям, а між ними і епископови в Сомбатгелю та професорам гімназії. [...]

Слідно, що наші заточенцї всюди старались освідомлювати чужинцїв про наш нарїд та про Україну, бо в многих місцевостях стрічав ся я з чужими людьми, що дуже інтересувались українським питанєм.

Рудович І., о. Наше духовенство на воєнній еміграції. Нива. 1916. Ч. 7-8. Липень і серпень. С. 375-377.

\section{Додаток 5}

\section{Уривок зі статті о. І. Рудовича «Наше духовенство на воснній еміграції»}

За згодою Апостольського воєнного вікаріяту обняли священники емігранти духовну обслугу греко кат. жовнірів в шпиталях та заведенях здоровля у Відни і в околицї. А була се робота дуже важна з огляду церковного і національного. Наші хорі жовніри приїздили до Відня [...] з перших тижнів мобілізації в Галичині 1914 р.; більшість подавала свою народність «Галичанин», а заряди вписували наших Українців як «Рole» або «Rumäne», «Slovak», «Ungar» і т. ін. Коли приходив наш священик капелян до хорих, довідував ся від заряду шпиталю на основі урядових записок, що там є всего 2 або 3 Українці; були се звичайно наші свідомі селяни або інтелїгенти. При помочи наших людий зачиналось вишукуванє вірних, та протягом кількох днів находилось кількадесятьох Українців. На інтервенцію о. капеляна, а деколи і наших пань і панів, що відвідували українських ранених жовнїрів, управи шпиталів справляли похибки що до народности хорих. Головну увагу клало наше духовенство на душпастирську працю між хорими жовнїрами і несло слова потіхи і релігійної відради борцям, перетомленим тяжким трудом в борбах за вітчизну, фізично зломаним ранами і болем, духово прибитим та занепокоєним о судьбу дорогої їм родини, від якої нераз не мали анї одної вісточки від хвилї покликання до чинної служби. Справу української католицької Церкви 
поставили оо. капеляни зовсїм ясно, а се спричинило з початку переминаючі колізії, особливо там, де функції капелянів другого католицького обряду сповняли священики з Галичини. Та преосв. Епископ польний сейчас усував всяке тертя, які лиш дійшли до єго відома, та кождому признавав належні єму права. Ми не можемо уявити собі, якою радісною подією була поява українського капеляна для хорого жовніра, який нераз не міг порозумітись $з$ окружаючими єго людьми, не вмів розмовитись, та подїлитись своїм горем і болем з іноязичними товаришами недолї. Деяким закрутились слези в очах, коли священик повитав їх словами: «Слава Ісусу Христу», та заговорив до них по українськи. По всїх більших шпиталях були богослужебні каплиці, в яких відправлялось наше богослуженя що неділі і свята, а часто і в будні дні. В великих шпиталях, в яких були просторі каплиці, на богослуженях співав хор, зоргнізований [...]о. проф. Туркевичом з наших пань, богословів, академіків і учеників. Наша гарна пісня церковна стягала до каплиці всіх зі шпиталю; приходили жовніри всіх націй, хорі зволікались на милицях, а за ними ішли сестри, служба, та заряд шпиталю. До сповіди і причастя приступали ранені радо і часто. В маю відбувались по деяких шпиталях маєві богослуженя, на яких голошено короткі науки до жовнірів кілька разів в тижни. До наших отців горнулись не лиш Галичани, але і Українці з Угорщини, які дуже любувались нашою «необщипаною» - як вони висловлювались - себ то нескорочуваною самовільно Службою Божою, та просили о українські молитвенники, в яких - після їх думки «божественні молитви, мова і лїтери». Буковинці, навіть православні - приходили до наших отців - як до своїх - 3 повним довірєм і щиростию. Отцї капеляни стали для наших хорих жовнірів не лиш душпастирями, але дорадниками, приятелями, заступниками та посередниками в кореспонденції. Неграмотним писали листи до родини і висилали їх до Галичини, письменним роздавали часописи і молитвослови. Найрадше читали наші жовніри Місіонаря, який видавали оо. Василіяни в Загребі. Зокрема що до заосмотреня наших жовнірів в молитвослови і опіки над ними треба піднести вельми щиру працю Українського Жіночого Комітету, що завязав ся у Відни в осени 1914 р. [...] Скарбником того комітету був о. Василь Лициняк. Духовенство, перебуваюче у Відні, обслуговувало 170 шпиталів у Відні і 26 в найблизшій окресности[...] Число хорих жовнірів змінялося майже кождого тижня; найбільше було в зимі 1914 р. і на весні 1915 і доходило до 8.000, а 15 липня 1915 р. лишилось у Відни 2.250, а в околици поза Віднем 1.156 хорих. Апостольський вікаріят польний видав 79 нашим священикам відповідні лєгітимації, які управняли їх сповняти душпастирські обовязки між хорими і раненими жовнірами по зелізничих стаціях, шпиталях і всяких військових заведенях воєнного терену. Управи шпиталів з признанєм підносили безінтересовну працю та корректне поведенє оо. капелянів; деякі отці - а з поміж катихитів о. Софрон Глїбовицький з Бродів о. шамб. Погорецький з Ярослава - дістали відзнаки і узнанє за повну посвяти працю. 3 початком червня 1915 р. стали вертати збігці священики до Галичини, а тодї військова управа заіменувала для віденських шпиталів двох гр. кат. резервових військових душпастирів, яким помагає двох наших священиків. Референтом шпитальних справ був довший час о. Др. Скобельський Лев, завідатель Жидачева, а опісля о. Софрон Глїбовицький і о. Корнило Кузик з Радимна. І в інших краях наші священики дуже щиро занялись нашими жовнірами, а особливо хорими».

Рудович І., о. Наше духовенство на воєнній еміграції. Нива. 1916. Ч. 7-8. Липень і серпень. С. 373-375. 


\section{Додаток 6}

Воснна статистика гр. кат. військових куратів до кінця р. 1915

Померли оо.: 1) Віктор Кізак († 4/1 1916 у Львові на віспу); 2) Модест Соболта († 5/4 1915 в Гомоннї на черевний тиф) і 3) Щасний Щурко († 4/9 1914 в Nagymihaly на холєру).

Полонені оо: 1) Онуфрій Гадзевич (в Росії); 2) Володимир Котис; 3) Антін Ломницький (в Сиберіі); 4) Володимир Садовський (в Росії); 5) Василь Телішевський (в Росії); 6) Михайло Зїнкевич і 7) Юрій Ришта.

Bidзначені оо.: 1) Антін Цегельський, 2) Володислав Хмільовський, 3) Максимілїян Хома, 4) Юрій Дарабант, 5) Йосиф Добранський, 6) Андрій Гаврищак, 7) Теофіль Гординський, 8) Стефан Гірняк, 9) Йосиф Ільницький, 10) Іван Ісаїв, 11) Николай Їжак, 12) Теодат Ярема, 13) Антін Калята, 14) Мирон Колтунюк, 15) Александер Ковальський, 16) Константин Козій, 17) Д-р Николай Нагорянський, 18) Григорій Островський, 19) Іван Озимкевич, 20) Дмитро Панасевич, 21) Василь Пелех, 22) Михайло Прокурат, 23) Стефан Проскурницький, 24) Николай Притуляк, 25) Йосиф Рачковський, 26) Юрій Рус, 27) Йосиф Шах, 28) Лев. І. Сембратович, 29) Володимир Шебец, 30) Стефан Воробець і 31) Станислав Возняк.

Аванзували оо.: 1) Шамбелян Кассіан Куницький посунений до VII ранги; 2) Антін Ломницький і Йосиф Кишакевич іменовані старшими полевими куратами.

На всїх військових австро-угорських католицьких куратів убитий до кінця 1915 р. - один; померло - 11 (в тім гр. кат. 3); ранених 10; полонених 41 (в тім гр. кат. 7); відзначених 530 (в тім гр. кат. всього на всього 31!).

Нива. 1916. Ч. 7-8. Липень і серпень. С. 426-427.

\section{Додаток 7}

Казала дівчина

Ця пісня зложена в 1917 р. Співали їі найбільще старшина УСС у столовій, як були добре настроєні до свойого поевого духовника ${ }^{81}$

Сл. імуз. Л. Лепкого

1. Казала дівчина казала,

Що буде вірно кохала,

Що, що, що буде за другого не піде. (2)

2. Як я їхав то вмлівала,

А поїхав, другому дала

Рученьку білую, сама пішла під вінець. (2)

3. Казав мені курат на сповіди,

Щоб я не шукав собі біди:

«Жий, жий так як як, все жию без гріха». (2)

81 Ноти пісні скопійовано зі сайту «Наше. Тексти пісень». URL: https:/nashe.com.ua/ song/16494/notes 
4. Казав мені курат уважати

Молодиць не зачіпати:

«Жий, жий! Уважай! Молодиць не заіпай»! (2)

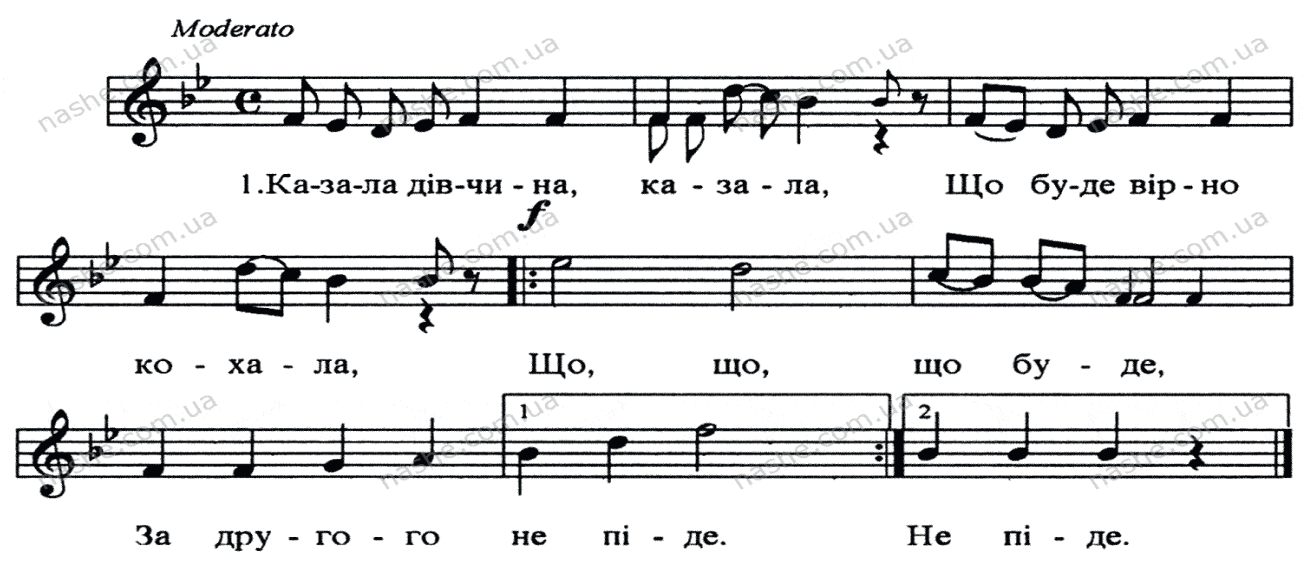

Сурма. Збірник воєнних пісень. Львів-Київ: Накладом видавничої спілки «Червона Калина», 1922. С. 108. 